\title{
Life History of Female Preferences for Male Faces
}

\section{A Comparison of Pubescent Girls, Nonpregnant and Pregnant Young Women, and Middle-aged Women}

\author{
Krzysztof Kościński
}

Published online: 17 September 2011

(C) The Author(s) 2011. This article is published with open access at Springerlink.com

\begin{abstract}
Although scientific interest in facial attractiveness has developed substantially in recent years, few studies have contributed to our understanding of the ontogeny of facial preferences. In this study, attractiveness of 30 male faces was evaluated by four female groups: girls at puberty, nonpregnant and pregnant young women, and middleaged women. The main findings are as follows: (1) Preference for sexy-looking faces was strongest in young, nonpregnant women. (2) Biologically more mature girls displayed more adultlike preferences. (3) The intragroup consistency for postmenopausal women was relatively low. (4) In terms of the preference pattern, pregnant women were more similar to perimenopausal women than they were to their nonpregnant peers. (5) Preference for youthful appearance decreased with the age of the women. I argue that the life history of female preferences for male faces is, to a large extent, hormone-driven and underpinned by a set of evolutionary adaptations.
\end{abstract}

Abstract W ostatnich latach znacznie wzrosło zainteresowanie naukowców atrakcyjnością twarzy, niewiele jednak badań przeprowadzono nad ontogenezą preferencji dla twarzy. W niniejszej pracy, atrakcyjność 30 twarzy mężczyzn była oceniana przez cztery grupy kobiet: dziewczęta w okresie pokwitania, nieciężarne i ciężarne młode kobiety oraz kobiety w średnim wieku. Uzyskano następujące wyniki: (1) Preferencja dla seksownie wyglądających twarzy była najsilniejsza u młodych, nieciężarnych kobiet. (2) Dojrzałość biologiczna dziewcząt dodatnio korelowała ze stopniem podobieństwa ich preferencji do preferencji dorosłych kobiet. (3) Wewnątrzgrupowa zgodność kobiet po menopauzie była stosunkowo niska. (4) Pod względem sposobu postrzegania atrakcyjności, kobiety ciężarne odbiegały od swych nieciężarnych rówieśniczek i były stosunkowo podobne do kobiet w wieku średnim. (5) Preferencja dla młodzieńczego wyglądu słabła wraz z wiekiem oceniającej kobiety. Otrzymane wyniki sugerują, że zmiany preferencji w ciagu życia są w dużym stopniu uwarunkowane hormonalnie i są wyrazem ewolucyjnych przystosowań.

K. Kościński $(\bowtie)$

Institute of Anthropology, Faculty of Biology, Adam Mickiewicz University, Umultowska 89,

61-614 Poznan, Poland

e-mail: koscinski@amu.edu.pl 
Keywords Facial attractiveness $\cdot$ Ontogeny $\cdot$ Development $\cdot$ Sex hormones ·

Adaptation

A psychoevolutionary perspective on facial preferences has recently become very popular (Kościński 2007, 2008; Rhodes 2006). It posits that the perception of facial attractiveness is an evolutionary adaptation whereby pursuit of and contact with attractive individuals would be beneficial for one's reproductive success (Gangestad and Scheyd 2005; Symons 1995). Since the adaptive interests of an individual change with age, natural selection is believed to have made mental functions such as interests, desires, concerns, and judgments dependent on the individual's age (Buss 1999). Thus, the importance of various characteristics of a potential partner may depend on an individual's age, and consequently facial cues to these characteristics may be variously valued at different stages of life. For example, the reproductive success of infertile individuals (those before puberty or after the climacteric) cannot be enhanced by sexual intercourse. They are thus expected to show less preference for sexy persons and sexy-looking faces.

Facial preferences of people other than young adults, however, have thus far not been studied to any great extent. Infants at various ages (Langlois et al. 1987; 1991) and even 3-day-old newborns (Slater et al. 1998) preferentially look at the faces regarded by adults as attractive. Cooper et al. (2006) found that 4- and 9-year-old children preferred female faces with more childlike proportions than did 12-year-old children and adults. Saxton et al. (2006) studied two groups of girls aged 7-10 and 12-15 years, as well as adult women. All groups assessed the attractiveness of male faces very similarly, but the older the group, the greater the intragroup consistency of judgments. Saxton et al. (2009a) presented 11- and 13-year-old girls and boys with digitally manipulated faces of their respective peers. All groups displayed a preference for male and female faces that were feminine, symmetrical, and had typical proportions; this reflected the same preference pattern as that characteristic of adults. These preferences were more pronounced in the older group of children than in the younger. The authors also found some evidence for the dependence of preferences for faces and voices on the stage of a child's biological development, although the sexual maturity of girls and boys was unrelated to their evaluations of faces of the opposite sex.

Jones et al. (2005b) observed that the preference for healthy-looking faces was stronger in pregnant than in nonpregnant women. This may be an adaptation for avoiding a contagion since the immune system is depressed during pregnancy and the fetus is vulnerable (Sherman and Flaxman 2002). Little et al. (2007a) found that pregnant or lactating women more strongly preferred male facial symmetry than did other women. This result is unexpected because female preference for symmetry is underpinned by the willingness to gain good genes, rather than good care (Little et al. 2007b; Thornhill and Gangestad 1993). Facial symmetry should therefore be more strongly preferred by nonpregnant than by pregnant women. Older individuals display relatively weak preference for faces of young people (Mathes et al. 1985; Udry 1965), which reflects the fact that the older a person is, the weaker the preference for a younger potential partner (Buunk et al. 2001). Vukovic et al. (2009) reported that preference for masculine male faces in 40- to 64-year-old women 
decreased with age, but the effect of menopause was not clear. Little et al. (2010) found that digitally masculinized male faces were preferred more strongly by reproductive-age women than by pubescent girls or postmenopausal women.

\section{Present Study}

The aim of the present study was to compare facial preferences of four female groups: pubescent girls, young nonpregnant and pregnant women, and middle-aged women. All participants assessed attractiveness of the same faces of 30 young men. The groups of women differ from one another in terms of the ecological and developmental tasks they face. Girls at puberty advance from childhood and prepare for adult life; young, nonpregnant women seek a mate with whom to form a bond, beget, and raise children; pregnant women invest strongly in the child on the way; and middle-aged women, either pre- or postmenopausal, show an increased interest in their children's reproduction at the expense of their own. These differences in adaptive tasks may be reflected in the criteria for evaluating other people and also in facial preferences.

Both age and pregnancy are associated with different levels of sex hormones. Irrespective of the menstrual cycle phase, young, nonpregnant women have estradiol and progesterone levels many times higher than those of prepubertal girls and women 2 years or more after menopause but many times lower than women in the final trimester of pregnancy (Burger et al. 2002; Fleming et al. 1997; Winter 1978). Hormonal influences on facial preferences have been documented repeatedly (Jones et al. 2008; Roney and Simmons 2008; Theodoridou et al. 2009; Welling et al. 2007, 2008), so in the current study diversity in hormone profiles among female groups is expected to be associated with diversity in facial preferences. Cognitive factors may also play a role in facial preferences, including the development of social perception at puberty (McGivern et al. 2002), lifetime accumulation of perceptual and social experience (Jones et al. 2007), and brain aging (Coffey et al. 2001). A diversity of facial preferences among the four female groups is therefore anticipated both on ultimate (adaptive) and proximate (physiological and cognitive) grounds.

Although use of hormonal contraceptives and stage of menstrual cycle are associated with sex hormone levels and are known to affect facial preferences (Jones et al. 2008; Penton-Voak and Perrett 2000), they were not the focus of the present study. As pointed out above, the levels of estrogen and progesterone in pubescent, pregnant, and postmenopausal females are outside the range present in young, nonpregnant women. On the other hand, the concentrations of these hormones in women using hormonal contraceptives are within the range typical for naturally cycling women (Rosen and López 2009). Young, nonpregnant women were therefore treated as a single group irrespective of phase of menstrual cycle and use of hormonal contraceptives. Nonetheless, results of analysis with the pill users excluded are reported below when they differ from those obtained for all nonpregnant women.

Separate groups of young women judged the faces in terms of youthfulness, skin health, level of contentment based on the appearance of the mouth, and suitability for a short-term bond, a long-term bond, and for friendship. All of 
these traits are important in mate choice (Buss 1999; Buss and Schmitt 1993) and influence the perception of facial attractiveness (Burt et al. 2007; DeBruine et al. 2008; Johnston et al. 2001; Jones et al. 2004; Keating and Doyle 2002; Mathes et al. 1985; Rhodes et al. 1999). Using these supplementary evaluations of facial features in our analyses enabled us to estimate the degree to which these traits were preferred by each of the women. The attractiveness assessments by the four female groups were then analyzed for three aspects: (1) the strength of preference for those facial features, (2) intergroup similarity of the attractiveness assessments, and (3) intragroup consistency of the attractiveness assessments. Several predictive hypotheses were formulated prior to, and on the basis of this method of, analysis:

Hypothesis 1 The preference for facial youthfulness decreases with the woman's age. This finding has already been reported by Mathes et al. (1985) and Udry (1965), and we simply expect to repeat the finding.

Hypothesis 2 Sexy-looking faces - in other words, those appropriate for a shortterm bond, are preferred most strongly by young, nonpregnant women. The main benefit to be gained by a woman from a short-term partner are good genes that can be passed on to offspring (Gangestad and Scheyd 2005; Geary et al. 2004), and women would therefore be expected to prefer cues to good genes in the faces assessed for such a bond. Cues to good genes that are strongly preferred by women in the context of a short-term relationship include facial masculinity (Johnston et al. 2001) and symmetry (Little et al. 2007b), as well as faces of men who have high levels of testosterone, another indicator of genetic quality (Roney et al. 2006). Furthermore, young women prefer masculine male faces more than do pubescent girls and postmenopausal women (Little et al. 2010). Girls at puberty, pregnant women, and middle-aged women are infertile (non-ovulating) or subfertile (of low reproductive capacity). Sperm containing good genes is thus most beneficial for young, currently nonpregnant women, and this group is expected to most strongly prefer sexy-looking faces.

Hypothesis 3 Pregnant women prefer friendly-looking faces more than nonpregnant women do. Pregnant women, especially in the last trimester, are physically less fit and feel dependent and in need of care (Leifer 1977). They may therefore prefer more contacts with individuals of good character. Women in the luteal phase of the menstrual cycle display enhanced preference for feminized or self-resembling male and female faces (DeBruine 2005; Jones et al. 2005a) - in other words, those that suggest a relatively high probability of offering support (DeBruine 2005; Perrett et al. 1998). The preferences for facial femininity and self-resemblance manifested in the luteal phase are interpreted as by-products of functional preferences at pregnancy, when the woman is seeking support from helpful people or relatives (Jones et al. 2008).

Hypothesis 4 The level of sexual maturity of girls is associated with their facial preferences. Specifically, pubertal development, measured by age at menarche and breast development, is expected to be associated with the more adultlike 
pattern of preferences. During puberty, levels of sex hormones (estrogens, progesterone, and testosterone) increase substantially in both sexes (Winter 1978). These hormones are related to sexual drive and facial preferences of adult women (Jones et al. 2008; Roney and Simmons 2008; Scarbrough and Johnston 2005; Welling et al. 2007), so their increase at puberty may sensitize girls to male-typical facial features and mold an adultlike neural apparatus for perceiving attractiveness.

Hypothesis 5 Postmenopausal women are less consistent in their judgments of attractiveness than young women and their premenopausal peers. Some cognitive abilities decrease with age - for example, the ability to distinguish facial patterns in reduced light (Hayes and Minardi 2005). Estrogens activate the visual cortex (Williams 1998) and alleviate regression of cognitive abilities at old age (Lebrun et al. 2005). Estrogen levels rapidly decrease at menopause (Burger et al. 2002), which may lead to an increase in variation in attractiveness ratings among postmenopausal women.

Hypothesis 6 Pregnant women tend to be less like their nonpregnant peers and more like premenopausal middle-aged women in regard to preference pattern. Although pregnant women and premenopausal middle-aged women are purported to be as efficient in facial processing as young, nonpregnant women, both are expected to value the sexy look relatively weakly (see Hypothesis 2). This may result in their preferences being somewhat convergent.

\section{Methods}

\section{Stimuli}

Full-face color photographs of 45 male students (19-25 years old, European origin) were taken from a distance of $3 \mathrm{~m}$ with a digital camera (Fuji S7000, 6 Mpix). Posers displayed neutral expressions with a direct gaze; they did not wear glasses and their hair was swept back from their faces. Photos of 30 clean-shaven men were selected for the present study. Each photo was whitemasked to hide all elements around the face and then printed in color on glossy paper $(330 \mathrm{dpi}, 7 \times 7 \mathrm{~cm})$ and numbered on the back. For the purposes of skin health assessments, three rectangular sections were extracted from each photo, one from each cheek and one from the forehead. These regions were chosen because they give no cues to facial geometry. For the purposes of judging contentedness using the appearance of the mouth, the area surrounding and including the lips was extracted from each photo.

\section{Participants}

Participants (all Caucasian) were from Poznań, a relatively affluent city in western Poland, minimally diversified in terms of socioeconomic status (e.g., it has no slums), ethnicity, and religious affiliation (Catholics constitute about 
$90 \%$ of the inhabitants). The following female groups made facial attractiveness judgments: (1) 59 girls (13.2-14.2 years old, $M=13.6)$ recruited from two schools; (2) 85 young, nonpregnant women (16.6-34.3 years old, $M=23.3$ ), mainly students in local colleges; (3) 38 pregnant women (20.0-32.3 years old, $M=27.2$ ) in the last trimester of their pregnancies ( $\geq 28$ th week, $M=34.6)$, all participants in state and private prenatal classes; and (4) 37 middle-aged women (45.0-60.1 years old, $M=52.9$ ), a sample of workers at two factories. Attractiveness ratings by 13 participants (five girls, five nonpregnant women, two pregnant women, and one middle-aged woman) correlated poorly with others in their respective groups $(r<$ 0.3 ). Based on the author's experience, such low correlations frequently reflect negligent performance on the part of participants (i.e., they chose randomly or too quickly), so the judgments of these females were excluded from the analysis (the above numbers reflect sample sizes after the exclusion). Informed consent was provided by all participants or, in the case of girls, by their parents.

The group of young, nonpregnant women was divided into two subgroups, younger $(N=47,16.6-23.0$ years old, $M=20.9)$ and older $(N=38,23.1-34.3$ years old, $M=$ 26.3). The older group did not differ significantly from the group of pregnant women with respect to age $\left(t_{74}=1.25, P=0.23\right)$, the size of their place of origin, their income, and their educational level. The comparison of attractiveness ratings between these groups may therefore reveal the effects of pregnancy on perception of attractiveness. The following abbreviations are used: GIRLS - the group of 13-year-old girls, ADULT21the younger group of nonpregnant women, ADULT26 - the older group of the nonpregnant women, PREG - pregnant women, and MID - middle-aged women.

Several independent groups of young women (20-21 years of age) evaluated stimuli faces with respect to the perceived age $(N=19)$, skin health $(N=34)$, contentedness based on the appearance of the mouth $(N=15)$, and suitability for a short-term relationship $(N=40)$, a long-term relationship $(N=40)$, and friendship $(N=40)$. No woman from these groups participated in the attractiveness evaluations. All data were gathered in 2007.

\section{Procedure}

First, four young women ranked all 30 faces, which yielded approximate estimates of their attractiveness. Then the set of 30 faces was divided into three 10 -face series with similar distributions of attractiveness (i.e., each series contained some attractive, moderately attractive, and unattractive faces). This procedure was repeated twice, yielding three different sets of 30 faces. In this way, all series were standardized with regard to attractiveness, and the distribution of extraneous facial features was balanced across the sets of faces.

The main groups of judges evaluated attractiveness in the following way. Each woman saw one of three stimuli sets, and the series order within the set was balanced between judges. Ten photos (i.e., one series) were taken from the envelope and laid out in front of the judge. The judge sorted photos according to perceived attractiveness. After completing the task, another series was laid out for evaluation, and the experimenter wrote down the sequence that had just been arranged. In this way, all three facial series were sorted one by one, and each participant assessed all 30 faces.

After attractiveness evaluations, participants filled out a questionnaire. Girls were asked several questions related to their biological and psychosexual development. 
From among five drawings depicting stages of female breast development (Tanner 1962), they pointed at the one best corresponding to their own breasts. Their biology teacher familiarized them with the stages beforehand. Girls also provided their date of menarche (or the time elapsed since it took place), if any, and answered whether they wanted to go out with a boy and whether they take care of their appearance so as to appeal to boys (on a 3-point scale of "yes" to "somewhat" to "no"). Factor analysis of these four characteristics (with varimax rotation) yielded two clear-cut factors: the first was loaded chiefly on the time elapsed since menarche (a factor loading of 0.84 ) and breast development (0.84), and the second on willingness to go out with a boy (0.83) and care for one's appearance (0.82). These were termed the biological and the psychosexual maturity indices, respectively, and the value of each was calculated for each girl. Pregnant women provided their expected delivery date, which was used to estimate pregnancy duration. Middle-aged women provided their age at menopause, if any (two women with surgically induced menopause were excluded from the sample, reducing its size from 39 to 37 ).

The women who assessed facial youthfulness or suitability for a short-term relationship, long-term relationship, or friendship followed the same procedure as those who assessed attractiveness. Notions of short- and long-term bonds were explicated in a way similar to that used by Penton-Voak et al. (2003). Skin health and perceived contentedness based on the appearance of the mouth were assessed on a computer monitor. Skin health was rated on a 5-point scale. The appearance of the mouth was rated on a scale from 1 ("distinct discontentment - sadness or anger") to 5 ("distinct contentment"). The evaluations of these six features were reliable (all Cronbach's alpha values $\geq 0.88$ ) so they were averaged across all raters, yielding estimates of youthfulness, skin health, contentedness, and suitability for a short-term relationship, a long-term relationship, and friendship. For brevity, the last three characteristics will be referred to as faces that appear sexy, marriageable, and friendly, respectively.

\section{Analysis}

Facial attractiveness can be regarded as normally distributed (Jones et al. 2001). The values of facial attractiveness (from 1 to 10 ) ranked by participants were transformed into standard normal values as follows: $\Phi^{-1}[(\operatorname{rank}-3 / 8) /(10+1 / 4)]$, where $\Phi^{-1}$ is the inverse standard normal cumulative distribution function (Blom 1958). Resultant values were multiplied by -1 , so the ranking number 1 (indicating the most attractive face) took the greatest normal value. All statistical analyses were conducted on these values. Tests were two-tailed, and the statistical significance was set at $p=0.05$. Correlations were determined using Pearson's product-moment. The other statistical methods are described in the relevant sections of the Results.

\section{Results}

Intragroup Consistency

Levels of within-group consistency in the perception of attractiveness were compared in the following manner. The standard deviation of attractiveness ratings by a group's 
members was determined for each face and each group. If two groups are equally consistent, the SDs for any face should be similar to each other. The equality of consistencies of two judging groups was tested with the Wilcoxon signed-rank test, where the SD of attractiveness ratings of a face by one group was treated as a single observation.

To confirm whether intragroup consistency in attractiveness assessments depended on female menopausal status, the middle-aged women (MID) were divided into two roughly equinumerous groups: women at most 2 years after menopause, if any (the PERI-MENO group, $N=20$ ) and women more than 2 years after menopause (the POSTMENO group, $N=17$ ). The consistency of POST-MENO women was significantly lower than that of PERI-MENO women (Wilcoxon test: $N=30, T=100, Z=2.73, P=0.006$, Fig. 1). POST-MENO women are, of course, older than PERI-MENO ones (55.6 vs. 50.7 years), so intragroup consistency may reflect calendrical rather than biological age. In order to verify this possibility, the MID group was divided into two age groups: up to 52 years old $(N=18)$ and more than 52 years old $(N=19)$. These groups' intragroup consistencies did not differ significantly (Wilcoxon test: $N=30, T=149, Z=1.72, P=$ 0.09 ), indicating that the intragroup consistency was underpinned by biological rather than calendrical age. PERI-MENO and POST-MENO groups are therefore treated separately in subsequent analysis. GIRLS, ADULT21, ADULT26, PREG, and PERI-MENO groups all displayed similar consistencies (all Wilcoxon $P$ values $>0.36$, Fig. 1). Also, girls' consistency did not depend on their biological or psychosexual maturity indices (not shown).

\section{Intergroup Similarities}

All intergroup correlations in the assessment of facial attractiveness were strong (all $r$ values $>0.7$, all $P$ values $<0.001$, Table 1 ). To obtain the pattern of intergroup

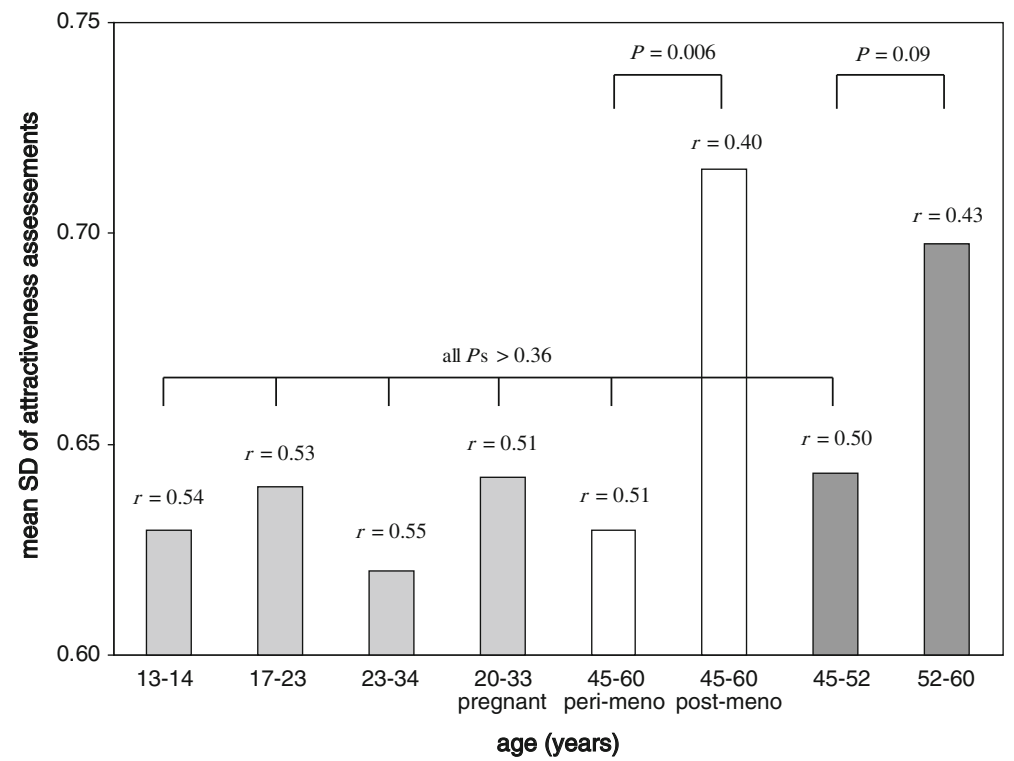

Fig. 1 The mean intragroup SDs of attractiveness assessments ( $y$ axis), the mean intragroup correlation coefficients ( $r$ values), and the Wilcoxon test's $p$-levels for the equalities of intragroup consistencies. The groups are defined in the text 
Table 1 Intergroup correlations of facial attractiveness assessments $(N=30$, all $P$ values $<0.001)$

\begin{tabular}{|c|c|c|c|c|c|}
\hline Age group (yrs) & $13-14$ & $17-23$ & $23-34$ & 20-33 pregnant & 45-60 perimenopausal $^{\mathrm{a}}$ \\
\hline $17-23$ & 0.95 & & & & \\
\hline $23-34$ & 0.93 & 0.98 & & & \\
\hline 20-33 pregnant & 0.86 & 0.92 & 0.95 & & \\
\hline 45-60 perimenopausal & 0.82 & 0.89 & 0.93 & 0.92 & \\
\hline 45-60 postmenopausal $^{\mathrm{b}}$ & 0.73 & 0.83 & 0.88 & 0.89 & 0.93 \\
\hline
\end{tabular}

${ }^{\text {a }}$ Women at most 2 years after menopause

${ }^{\mathrm{b}}$ Women more than 2 years after menopause

similarities, cluster analysis of attractiveness assessments was conducted. The analysis yielded one cluster containing the ADULT21, ADULT26, and GIRLS groups and another one containing the PERI-MENO and POST-MENO groups (Fig. 2). The clustering corresponded with the age variation, although the PREG group was included in the second cluster. Therefore, pregnant women appeared to be more similar to the much older MID women (older by 26 years, on average) than to roughly same-aged nonpregnant women and to girls who were not much younger (13 years, on average).

The above statistics give rise to the following questions: (1) Are pregnant women more similar to their nonpregnant peers or to PERI-MENO women? (2) Are ADULT26 women more similar to their pregnant peers or to ADULT21 women? (3) Are PERIMENO women more similar to POST-MENO women or to ADULT26 ones? The following method was applied to check whether one group $(G)$ is more similar to $X$ or to $Y$ group. For each face, the absolute difference between the mean evaluation by $G$ group and the mean evaluation by $X$ group was determined. The ensuing $G X$ variable $(N=30)$ was a measure of the distance between $G$ and $X$ groups in attractiveness perception. Processing of analogous $G$ and $Y$ groups' data yielded the $G Y$ variable. If $G$ group is equally similar to $X$ and $Y$ groups, then the values of $G X$ should be similar to the values of GY. This hypothesis of equality was tested with the Wilcoxon signed-rank test.

Fig. 2 Cluster analysis of attractiveness assessments by female group. The grouping method for the results shown here was average linkage clustering, although the Ward's method yielded a similar outcome

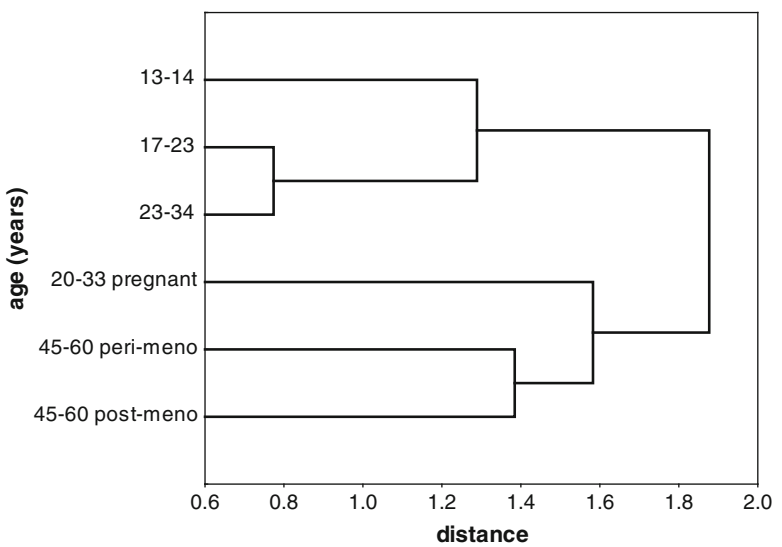


Table 2 presents selected intergroup distances and results of the Wilcoxon tests of the equality of those distances. These tests demonstrated that: (1) Pregnant women were equally similar to much older PERI-MENO women and to nonpregnant peers $(P=$ 0.14). (2) ADULT26 women were marginally more similar to ADULT21 women than to their pregnant peers $(P=0.06)$. This difference, however, attained significance when the women using hormonal contraceptives were excluded $\left(N_{\text {ADULT21 }}=40, N_{\text {ADULT26 }}=\right.$ 26, $T=125, Z=2.21, P=0.027$ ). (3) PERI-MENO women were equally similar to ADULT26 women and to POST-MENO ones $(P=0.16)$. The results support previous observations that the perception of attractiveness by MID (middle-aged) women depends on their biological age and that the preferences of pregnant women are relatively similar to those of the PERI-MENO women.

\section{Intergroup Differences in the Preference Pattern}

Finally, intergroup differences in the strength of preference for several facial features were analyzed. An individual's strength of preference for a facial feature was calculated as the correlation coefficient between the values of the feature and the attractiveness ratings by the person. The obtained values were then Fisher-transformed to make parametric tests applicable. In this manner, strengths of preference for skin health, contentedness, youthfulness, and for sexy, marriageable, and friendly faces were determined for each participant. A group's strength of preference for a facial feature was calculated as the mean of the group members' strength of preference for the feature. Figures 3 and 4 depict the mean strengths of preference for facial features by six groups: GIRLS, ADULT21, ADULT26, PREG, PERI-MENO, and POST-MENO.

One-way ANOVAs revealed that four of the groups - GIRLS, ADULT, PREG, and MID - differed in terms of their strength of preference for youthfulness, skin health, and for faces appearing sexy, marriageable, and friendly (all $P$ values $\leq 0.001$ ), but not for contentedness $(P=0.06)$. The results of subsequent Tukey tests (Table 3 ) demonstrated that:

- The preference for youthful appearance was stronger in the GIRLS group than in the PREG and MID groups, and also stronger in the ADULT than in the MID group.

- The MID group displayed a weaker preference for skin health than any other group.

- The preference for faces appearing sexy was stronger in the ADULT group than in the GIRLS and MID groups.

- The preference for faces appearing marriageable was weaker in the GIRLS group than in the ADULT and PREG groups.

- The preference for faces appearing friendly was weaker in the GIRLS group than in the ADULT, PREG, and MID groups.

(After ADULT21 was separated from ADULT26, and PERI-MENO from POST-MENO, the Tukey test yielded fewer significant results because of diminished group sizes and the larger number of comparisons.)

Comparing the ADULT26 and PREG groups with respect to preference for sexy faces is especially important in the present study. Although the Tukey test did not differentiate between them, the $t$-test indicated a stronger preference for sexy faces in 


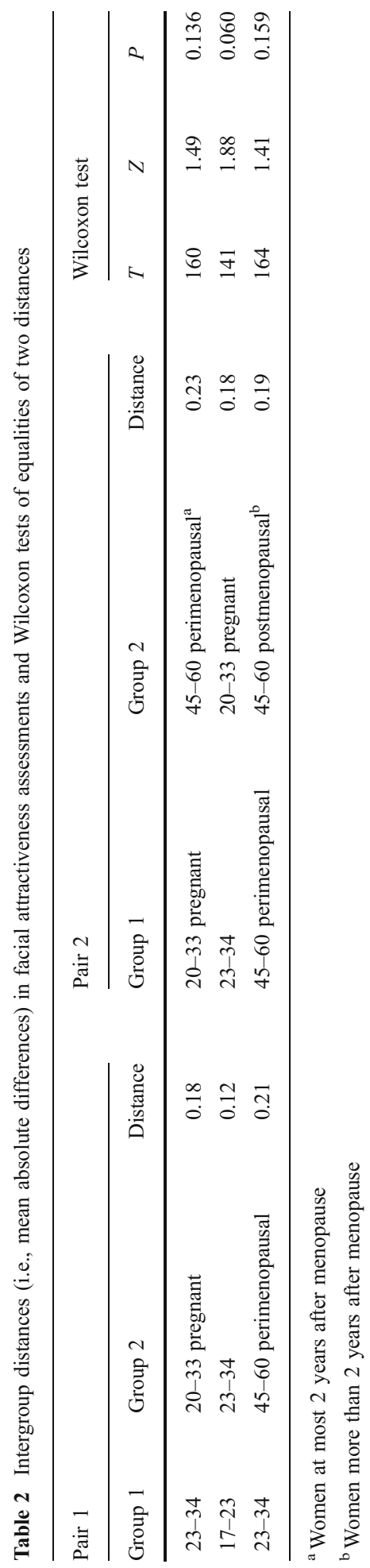




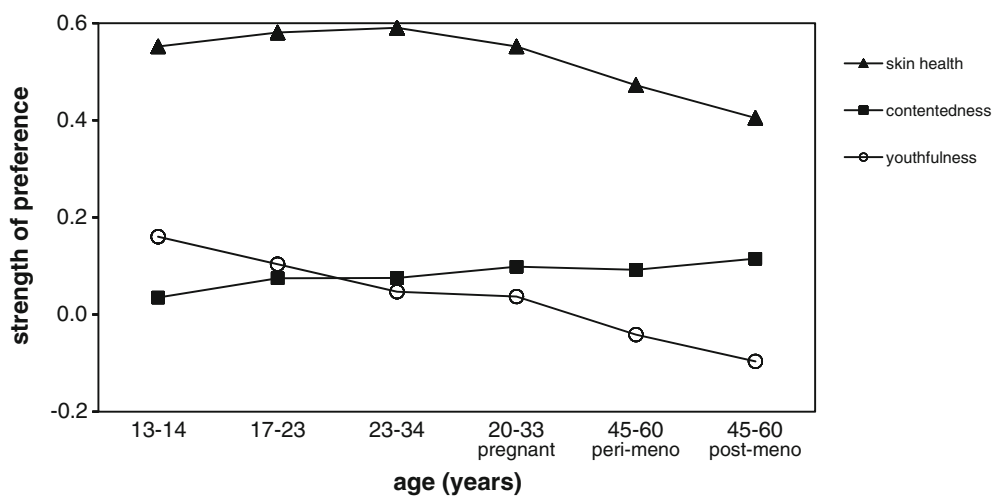

Fig. 3 Mean strengths of preferences for youthfulness, skin health, and contentedness as indicated by the position of the mouth, by female group

the ADULT26 women than in the pregnant ones $\left(M_{1}=0.88, M_{2}=0.78, t_{74}=2.05, P=\right.$ $0.044)$. This remained true even when only women currently in a relationship were considered (all 38 pregnant women and 27 of 38 their nonpregnant peers; $M_{1}=0.92$, $\left.M_{2}=0.78, t_{63}=2.51, P=0.015\right)$. The significance was lost, however, when pill users $(N=12)$ were excluded, regardless of whether women not in a pair bond were omitted (both $P$ values $>0.2$ ).

To determine whether girls' biological or psychosexual development affected their facial preferences, correlation coefficients were computed between the time elapsed since the menarche, stage of breast development, and index of psychosexual maturity, on one hand, and the strengths of preference for the six facial features and the correlation of facial assessments with the mean assessments by adult women, on the other hand. The analysis conducted on all 59 girls produced no significant correlations. However, visual inspection of scatter plots revealed the three girls with the lowest declared ages of menarche $(9.84,10.08$, and 11.09 years) to be twodimensional outliers. Given that the average age at menarche in large Polish cities is $13.1 \pm 1.1$ (Żarów and Cichocka 2008), the values of the first two girls correspond to $z$-scores of -3.0 and -2.7 , respectively. Very low age at menarche may result from a medical disorder (Traggiai and Stanhope 2003), and values below -2.5 are indicative

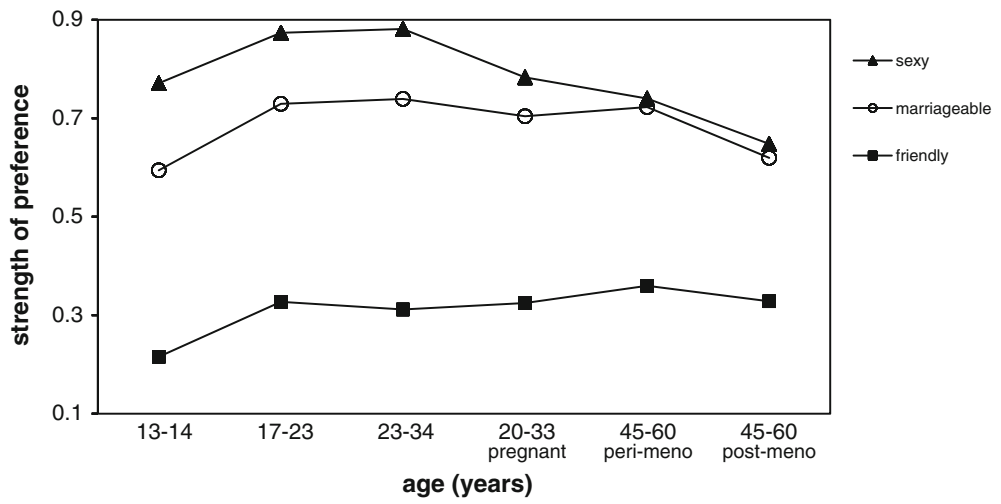

Fig. 4 Mean strengths of preferences for faces appearing sexy, marriageable, and friendly by female group 
Table 3 Mean strengths of preferences by female group and Tukey test $p$-levels for intergroup comparisons

\begin{tabular}{|c|c|c|c|c|}
\hline \multirow[b]{2}{*}{ Age group (yrs) } & \multirow[b]{2}{*}{$M$} & \multicolumn{3}{|c|}{ Age group (yrs) } \\
\hline & & $13-14$ & $17-34$ & 20-33 pregnant \\
\hline \multicolumn{5}{|l|}{ Youthfulness } \\
\hline $13-14$ & 0.160 & & & \\
\hline $17-34$ & 0.078 & 0.105 & & \\
\hline 20-33 pregnant & 0.037 & 0.031 & 0.795 & \\
\hline $45-60$ & -0.067 & 0.000 & 0.008 & 0.104 \\
\hline \multicolumn{5}{|l|}{ Skin health } \\
\hline $13-14$ & 0.552 & & & \\
\hline $17-34$ & 0.585 & 0.756 & & \\
\hline 20-33 pregnant & 0.552 & 1.000 & 0.857 & \\
\hline $45-60$ & 0.441 & 0.044 & 0.004 & 0.044 \\
\hline \multicolumn{5}{|l|}{ Contentedness } \\
\hline $13-14$ & 0.035 & & & \\
\hline $17-34$ & 0.075 & 0.386 & & \\
\hline 20-33 pregnant & 0.099 & 0.179 & 0.877 & \\
\hline $45-60$ & 0.103 & 0.144 & 0.820 & 0.999 \\
\hline \multicolumn{5}{|l|}{ Sexy } \\
\hline $13-14$ & 0.771 & & & \\
\hline $17-34$ & 0.877 & 0.043 & & \\
\hline 20-33 pregnant & 0.783 & 0.995 & 0.242 & \\
\hline $45-60$ & 0.698 & 0.476 & 0.003 & 0.340 \\
\hline \multicolumn{5}{|l|}{ Marriageable } \\
\hline $13-14$ & 0.594 & & & \\
\hline $17-34$ & 0.734 & 0.000 & & \\
\hline 20-33 pregnant & 0.704 & 0.031 & 0.881 & \\
\hline $45-60$ & 0.675 & 0.189 & 0.475 & 0.894 \\
\hline \multicolumn{5}{|l|}{ Friendly } \\
\hline $13-14$ & 0.216 & & & \\
\hline $17-34$ & 0.320 & 0.002 & & \\
\hline 20-33 pregnant & 0.325 & 0.014 & 0.999 & \\
\hline $45-60$ & 0.345 & 0.002 & 0.903 & 0.944 \\
\hline
\end{tabular}

of precocious puberty (National Institutes of Health 2010). The third girl was not as extreme in terms of menarcheal age $(z=-1.8)$, but she provided data indicating that her mother was only 15 years older than herself. This suggests that some data provided by the girl are incorrect or that her family background was extreme (the second-lowest declared age of the mother at childbirth in the sample was 18). The previous analysis was therefore repeated with these three girls excluded. For the resulting group of 56 girls, the time elapsed since menarche was positively correlated with a preference for faces sppearing sexy $(r=0.27, P=0.047)$, marriageable $(r=$ 
0.34, $P=0.009)$, and friendly $(r=0.26, P=0.049)$, and, marginally, with the preference for healthy skin $(r=0.26, P=0.057)$. It was also correlated with the adult women's preferences $(r=0.31, P=0.021)$. Breast development was positively associated with preference for sexy faces $(r=0.34, P=0.011)$, marriageability $(r=0.29, P=0.030)$, and with the adult women's preferences $(r=0.32, P=0.016)$. No similar associations were found for the index of psychosocial maturity (all $P$ values $>0.1$ ).

Although the effects of use of hormonal contraceptives and phase of the menstrual cycle on facial preferences were not the focus of the present study, we briefly report them here for all 85 young nonpregnant women combined. As shown by the $t$-test, pill users $(N=19)$ did not differ from nonusers $(N=66)$ in terms of strength of preference for any facial feature (all $P$ values $>0.1$ ). Next, among women not using hormonal contraceptives, those in the fertile and infertile phase of the menstrual cycle were identified. The day of the cycle relative to ovulation was established on the basis of declared cycle length and time since the previous menstruation, assuming that ovulation occurs 14 days prior to the start of the next cycle (Little et al. 2007b; owing to missing data this method could not be applied in the case of one woman). The period extending from 5 days before to 1 day after ovulation was regarded as the fertile period (Wilcox et al. 2001). Results of $t$-tests showed that women in the fertile phase of their cycles $(N=17)$, in comparison with those in the nonfertile phase $(N=48)$, manifested stronger preference for indicators of skin health $\left(M_{1}=0.68, M_{2}=0.57, t_{63}=\right.$ 2.51, $P=0.015)$ and youthful appearance $\left(M_{1}=0.18, M_{2}=0.04, t_{63}=2.62, P=0.011\right)$, and weaker preferences for contentedness $\left(M_{1}=0.01, M_{2}=0.09, t_{63}=2.00, P=0.050\right)$, marriageable faces $\left(M_{1}=0.65, M_{2}=0.75, t_{63}=2.01, P=0.049\right)$, and friendly faces $\left(M_{1}=\right.$ $\left.0.24, M_{2}=0.34, t_{63}=2.21, P=0.031\right)$. A nonsignificant effect was observed for the preference for sexy faces $\left(M_{1}=0.89, M_{2}=0.81, t_{63}=1.13, P=0.262\right)$. Because of a small sample size, these results should be taken with caution; nevertheless they concur with previous findings that cues to good biological quality (such as skin health) are preferred more strongly during the fertile phase, whereas cues to good personality (friendliness, contentedness, and possibly marriageability) are more valued in the nonfertile phase (e.g., Jones et al. 2008).

\section{Discussion}

The results support most of our predictions: the preference for youthful appearance decreased with a woman's age; the preference for sexy-looking faces was strongest in young, nonpregnant women; pregnant women were less like their nonpregnant peers and trended toward the judgments of middle-aged women; biological development of girls was related to the maturity of their preferences; and judgments by postmenopausal women were relatively inconsistent. The only prediction not supported by our results was that pregnant women would strongly prefer friendlylooking faces.

\section{Preference Development at Puberty}

In the present study, 13-year-old girls displayed a weaker preference for sexy, marriageable, or friendly faces than young, nonpregnant women. This suggests that 
the neural apparatus for facial evaluation is not yet fully mature at puberty. Nevertheless, previous studies have indicated that it is more developed at the age of 12 than at age 6: six-year-old girls prefer faces with more childlike proportions than do 12-year-old girls and adult women (Cooper et al. 2006), and they display a lower consistency of attractiveness judgments than 12- to 15-year-old girls (Saxton et al. 2006). One cause of the changes in attractiveness perception may be changes in sex hormone levels. At 10-12 years of age, the androgen levels in girls increase markedly (Winter 1978) and give rise to sexual drive and activity (Halpern et al. 1994, 1997). There is also a rapid rise in estrogen levels during puberty (Winter 1978), which may contribute to the cognitive developmental changes (Lebrun et al. 2005; Williams 1998). Hormonal changes at puberty reorganize the cerebral cortex (Sisk and Zehr 2005) and, presumably, also the neural apparatus for facial perception (Diamond et al. 1983; McGivern et al. 2002). Efficiency in recognition of facial identity (Itier and Taylor 2004) and expression (McGivern et al. 2002) develops throughout childhood and adolescence and is not fully mature prior to the age of 16 . Pubertal increase in sex hormones may thus be expected to contribute to the development of facial preferences at that time. The results of the present study support this conjecture since the level of biological development in girls, and not their psychosexual development, was associated with their preferences for facial cues of suitability for a short-term relationship, long-term relationship, and friendship, and with the degree of similarity to the preferences of adult women.

Normally, girls experience their first ovulation (i.e., become fecund) many months after they have begun to menstruate, attain a mature form (e.g., develop breasts), and feel sexual drive for the first time (Tanner 1962). Thus, we need to explain why stillinfertile girls perceive facial attractiveness much the same as adult women do, and why they prefer sexy male faces much more strongly than friendly-looking male faces. Girls who already have the adult feminine form, but are still infertile, can attract adult men and trade sex for meat and other goods without risk of impregnation (Bogin and Smith 1996; Symons 1979). They also have early opportunities to accrue experience in relationships with men, which would be helpful for their subsequent partner choices. Modulation of the innate mechanisms of facial perception by experience may facilitate the development of adultlike preferences for male faces: experiments have shown that if, among previouslyseen faces, a facial feature coexists with a negative stimulus (e.g., a harsh personality), then the observer will develop an aversion for other faces with that feature (Jones et al. 2007). The development of attractiveness perception in subsequent years may be stimulated by further increase in estrogen levels (Winter 1978) and cumulative individual experience of adultlike faces (Saxton et al. 2009b). In the present study, 17- to 23-year-old women displayed a preference pattern virtually identical to that of 23- to 34-year-old women in terms of both general similarity of assessments and strength of preferences for specific facial features. This suggests that facial attractiveness perception is already fully mature at about age 20 .

\section{Preference Changes in Adulthood}

Faces that make men appear suitable for a short-term bond (i.e., sexy faces) were preferred most strongly by young, nonpregnant women. As was previously 
mentioned, such faces presumably signal high genetic quality (Johnston et al. 2001; Little et al. 2007b; Roney et al. 2006) and should be valued most by highly fecund women (i.e., by young, nonpregnant women). These results were expected, from an evolutionary perspective. Preference for sexy faces decreased from young adulthood to middle age, as do testosterone level (Burger et al. 2002) and sexual drive (Bancroft 2002). The decrease in testosterone level may be responsible for the change in facial preference; several studies support this proposition. It has been suggested that variation of testosterone level within a menstrual cycle induces concomitant changes in female preference for masculine faces (Welling et al. 2007) -in other words, faces that are more strongly preferred in a sexual context (Burt et al. 2007; Johnston et al. 2001). Also, Welling et al. (2008) found that higher testosterone levels in men correlate with stronger preference for feminine, and thus sexier, female faces. Finally, Vukovic et al. (2009) found that preference for digitally masculinized male faces decreased with age in 40- to 64-year-old women, and this effect was not mediated by the subjects' menopausal state. This finding matches the gradual decrease of testosterone with age rather than the steep decrease in estrogen occurring around the time of menopause (Burger et al. 2002).

As women approach menopause, other preferences become adaptive for them. First, their fecundity (Henry 1961) and sexual drive (Bancroft 2002) decrease, so their desire would tend to be for a long-term rather than short-term relationship with a man. Second, in the majority of nonindustrialized populations, women participate in the selection of the spouse for their children (Apostolou 2007, 2010). Thus, perimenopausal women, relative to young women, should display less preference for sexy male faces but not for faces suggesting high marriage suitability. Our results support these predictions and indicate that the preference for male faces indicating suitability for marriage is consistent across a wide age range of women from age 20 to perimenopausal. Therefore, preference for long-term relationships does not diminish as long as the woman is still fertile. This preference tended to diminish only more than 2 years after menopause, as did the preference for a sexy appearance and healthy skin. These women also displayed a lower intragroup consistency than women who were, at most, 2 years after menopause, if any. It was demonstrated that this was the effect of their biological age (the time since menopause) rather than chronological age. The decrease in intragroup consistency suggests a regression of cognitive functions. Estrogen levels begin to fall rapidly roughly 2 years before menopause and stabilize about 2 years thereafter (Burger et al. 2002). Estrogen is beneficial for cognitive tasks and it activates the visual cortex (Lebrun et al. 2005; Williams 1998), so its perimenopausal decrease may be a causal factor in the concomitant loss of consistency in facial attractiveness perception. Similarly, Udry (1965) found a relatively poor consistency in women aged 55 and older, and thus postmenopausal, but explained it in terms of increased social isolation with age. The present results, however, suggest a hormonal basis. The role of hormones in the facial preferences of middle-aged women was also suggested by Little et al. (2010), who found that masculinity in male faces was preferred more strongly by premenopausal than by postmenopausal women, and that this effect was independent of the women's ages.

After menopause, women are infertile, so their sexual activity would have no impact on their reproductive success. Thus, natural selection exerts no pressure on 
their preferences related to partner choice. Menopausal decline in attractiveness perception is therefore understandable from an evolutionary perspective. A postmenopausal woman may, however, benefit from a friendship with a man, especially when the man cares for her descendants. According to this insight, postmenopausal women in the present study preferred friendly-looking male faces as much as premenopausal or young women did.

In accordance with our predictions, female preference for youthful appearance progressively decreased with age, from adolescence to middle age. This reflects an age-dependent preference for partner's age (Buunk et al. 2001; Mathes et al. 1985). Normally, each woman knows her own age, is aware of how youthful or mature she appears, knows that men prefer women of a particular age and that various characteristics of men (e.g., wealth, social status, the risk of death) are agedependent, and she experiences indications of interest from men of a specific age. These factors certainly and more or less consciously affect a woman's preference for men of a certain age (Pawłowski and Dunbar 1999). Experimental exposure to faces with a specific feature increases an individual's preference for other faces possessing that feature (Little et al. 2005; Rhodes et al. 2003), and, in natural conditions, the most frequently seen faces belong to persons similar in age to the observer (siblings, friends, schoolmates, spouses, etc.). Everyday experience of faces may therefore be another mechanism leading to the dependence on age of the observer's preference for a particular appearance (Saxton et al. 2009b). This age-dependent preference seems to be cognitively rather than hormonally derived.

\section{Preferences of Pregnant Women}

Women who are already pregnant cannot obtain genetic benefits from having sex with a man with good genes. Moreover, preference for men with cues to good genes may even be harmful because these men often have undesirable personalities (Waynforth 1999). Pregnant women, especially in the last trimester, are physically less fit and feel dependent and in need of care (Leifer 1977). Therefore, in comparison with nonpregnant women, they should weakly prefer sexy-looking male faces and strongly prefer friendly-looking faces. The present study confirms only the first part of this prediction (although the effect lost significance when pill users were excluded from the analysis, possibly because of reduced sample size). The decrease in preference for a sexy appearance during pregnancy may be caused by progesterone, which weakens sexual drive (Dixson 2001; Regan 1999), and its levels increase dramatically during pregnancy (Fleming et al. 1997). Our finding of a lack of heightened preference for a friendly appearance might result from the fact that all the pregnant women studied were in a relationship, and their need for having a friend-caregiver was already satisfied. One might expect the preference to be heightened in pregnant women who are not receiving satisfactory care from family and friends.

Jones et al. (2005b) found a stronger preference for healthy-looking faces in pregnant than in nonpregnant women and explained it in terms of contagion avoidance. The risk of infection is especially high during the first trimester of pregnancy (Sherman and Flaxman 2002), so enhanced preference for healthylooking faces may exist only in the early stage of gestation (Jones et al. studied 
women at various stages of pregnancy). The effect of pregnancy on preference for a healthy appearance may be absent in the present sample because it consisted of pregnant women only in the last trimester. If this reasoning is correct, the effect reported by Jones and coworkers is not dependant on progesterone levels because they increase throughout pregnancy. Instead, the effect might depend on the level of human chorionic gonadotropin or the ratio of progesterone to estrogen, both of which were shown to correlate with the aversion of pregnant women for potentially contaminated food and its smell (O’Connor et al. 1998).

Our results also support the prediction that pregnant women are less similar to their nonpregnant peers than they are to perimenopausal women: (1) The cluster analysis grouped young pregnant women together with middle-aged women rather than with girls and young nonpregnant women. (2) On the one hand, the degree of similarity of young pregnant women to perimenopausal women was much the same as the degree of their similarity to young nonpregnant women. On the other hand, the nonpregnant peers of the pregnant women $(M=26$ years) were marginally more similar to 21-year-old nonpregnant women than to the pregnant women. (3) Pregnant women displayed a weaker preference for sexy-looking faces than their nonpregnant peers, but not weaker than perimenopausal women $\left(t_{56}=0.74, P=0.46\right)$. Therefore, the patterns in facial preferences found in two groups of people may converge if their adaptive strategies are similar (e.g., both groups are only weakly interested in sexual relationships) even if their profiles of sex hormones are substantially different (e.g., the estrogen and progesterone levels in pregnant women are many times higher than they are in circummenopausal ones).

\section{Limitations and Future Directions}

The results of the present study should be considered in light of its limitations: The sample sizes were only several dozen individuals per group, and the judges viewed only 30 faces. Variation in and covariation of the features in the actual (not digitally generated or manipulated) faces were not controlled for. The results must therefore be confirmed by future studies. The lack of data on the use of hormone replacement therapy (HRT) by middle-aged women poses another concern. Since HRT changes a woman's hormonal state, it may affect her attractiveness evaluations. In Poland, however, only $7 \%$ of 45 - to 54 -yearold women are receiving HRT (Bińkowska et al. 2005), so we believe our results were not seriously impaired by the lack of data. Another limitation is that hormone levels were not measured in the present study even though the groups examined here undoubtedly differed markedly from one another in terms of hormone levels. Future research involving measurements of hormone levels in raters would be very useful.

There are also many other directions for future research. Thirteen-year-old girls are very similar to adult women in terms of the perception of facial attractiveness, so the child-to-adult transition should be looked for in somewhat younger children. Confirmation is needed for the supposition that pregnant women who are not receiving satisfactory care would strongly prefer friendly- 
looking faces. Studies involving a larger sample of postmenopausal women who are known to be using (or not using) HRT would also be valuable. It would be also interesting to determine whether lifetime changes in facial preference among non-Caucasian females follow those reported for Caucasian ones. Finally, longitudinal studies, in which each woman is examined at various stages of her life, would be a substantial methodological improvement. We are currently conducting a comparative longitudinal study of changes in female preference during pregnancy, puerperium, and afterwards.

\section{Conclusions}

The present study, in comparison with previous studies related to the ontogeny of facial preferences, is novel in several respects. First, several groups of women differing in age, some of whom were pregnant, rated the same 30 male faces, which enabled direct comparisons of their preferences. Second, several facial features important in social and mating contexts were determined. Third, this research attempted to reconstruct the ontogeny of female preferences for male faces, its hormonal and cognitive foundation, and its adaptive meaning.

Girls, young women, and middle-aged women differ from one another not only in hormonal status but also in many other ways (e.g., social environment) that might affect their preferences (Feser et al. 2007). Some of the results obtained, however, strongly suggest that sex hormones do contribute to variation in facial preferences. This pertains chiefly to girls and middle-aged women, whose perception of attractiveness depended on their biological maturity and menopausal status, respectively, both being strongly related to sex hormone levels. A hormonal effect on the preferences of pregnant women also seems probable since, in our sample, pregnant and nonpregnant women were closely matched in age and in certain other characteristics. Cognitive mechanisms have also been suggested to play a role, especially in the dependence of preference for youthful appearance on the observer's age.

Lifetime changes in female facial preferences seem to have a functional basis. This supports the psychoevolutionary standpoint that facial preferences are Darwinian adaptations. At the same time, it challenges nonadaptive views, such as the perceptual bias theory which posits that facial preferences are side-effects of modes of sensory organ and nervous system functioning (Enquist et al. 2002), or the social learning concept which claims that beauty standards originate on purely social grounds and spread as fashion (Wolf 1991).

Acknowledgments The author wishes to thank Alicja Borowiak, Aleksandra Gilewicz, Aleksandra Kuczera, Marta Lipińska, Justyna Reimann, Kaja Wysoczańska and Anna Dolata-Kościńska for their help in data collecting. He would also like to thank two anonymous reviewers and the editor for their helpful suggestions and comments on the earlier versions of the manuscript.

Open Access This article is distributed under the terms of the Creative Commons Attribution Noncommercial License which permits any noncommercial use, distribution, and reproduction in any medium, provided the original author(s) and source are credited. 


\section{References}

Apostolou, M. (2007). Sexual selection under parental choice: The role of parents in the evolution of human mating. Evolution and Human Behavior, 28, 403-409.

Apostolou, M. (2010). Sexual selection under parental choice in agropastoral societies. Evolution and Human Behavior, 31, 39-47.

Bancroft, J. (2002). Biological factors in human sexuality. Journal of Sex Research, 39, 15-21.

Bińkowska, M., Pietrzak, B., \& Dębski, R. (2005). Hormone replacement therapy in the group of Polish women aged 45-54 years. Knowledge, opinions, use. Przeglad Menopauzalny, 4, 19-27.

Blom, G. (1958). Statistical estimates and transformed beta-variables. New York: John Wiley \& Sons.

Bogin, B., \& Smith, B. H. (1996). Evolution of the human life cycle. American Journal of Human Biology, 8, 703-716.

Burger, H. G., Dudley, E. C., Robertson, D. M., \& Dennerstein, L. (2002). Hormonal changes in the menopause transition. Recent Progress in Hormone Research, 57, 257-275.

Burt, D. M., Kentridge, R. W., Good, J. M. M., Perrett, D. I., Tiddeman, B. P., \& Boothroyd, L. G. (2007). Q-cgi: New techniques to assess variation in perception applied to facial attractiveness. Proceedings of the Royal Society B, 274, 2779-2784.

Buss, D. (1999). Evolutionary psychology: The new science of the mind. Boston: Allyn \& Bacon.

Buss, D. M., \& Schmitt, D. P. (1993). Sexual strategies theory: An evolutionary perspective on human mating. Psychological Review, 100, 204-232.

Buunk, B. P., Dijkstra, P., Kenrick, D. T., \& Warntjes, A. (2001). Age preferences for mates as related to gender, own age, and involvement level. Evolution and Human Behavior, 22, 241-250.

Coffey, C. E., Ratcliff, G., Saxton, J. A., Bryan, R. N., Fried, L. P., \& Lucke, J. F. (2001). Cognitive correlates of human brain aging: A quantitative magnetic resonance imaging investigation. Journal of Neuropsychiatry and Clinical Neuroscience, 13, 471-485.

Cooper, P. A., Geldart, S. S., Mondloch, C. J., \& Maurer, D. (2006). Developmental changes in perceptions of attractiveness: A role of experience? Developmental Science, 9, 530-543.

DeBruine, L. M. (2005). Women's attractiveness judgments of self-resembling faces change across the menstrual cycle. Hormones and Behavior, 47, 379-383.

DeBruine, L. M., Little, A. C., Perrett, D. I., \& Jones, B. C. (2008). Social perception of facial resemblance in humans. Archives of Sexual Behavior, 37, 64-77.

Diamond, R., Carey, S., \& Back, K. J. (1983). Genetic influences on the development of spatial skills during early adolescence. Cognition, 13, 167-185.

Dixson, A. (2001). The evolution of neuroendocrine mechanisms regulating sexual behaviour in female primates. Reproduction, Fertility, and Development, 13, 599-607.

Enquist, M., Ghirlanda, S., Lundqvist, D., \& Wachtmeister, C. A. (2002). An ethological theory of attractiveness. In G. Rhodes \& A. Zebrowitz (Eds.), Facial attractiveness: Evolutionary, cognitive, and social perspectives (pp. 127-151). Westport: Ablex.

Feser, D. K., Gründl, M., Eisenmann-Klein, M., \& Prantl, L. (2007). Attractiveness of eyebrow position and shape in females depends on the age of the beholder. Aesthetic Plastic Surgery, 31, 154-160.

Fleming, A. S., Ruble, D., Krieger, H., \& Wong, P. Y. (1997). Hormonal and experiential correlates of maternal responsiveness during pregnancy and the puerperium in human mothers. Hormones and Behavior, 31, 145-158.

Gangestad, S. W., \& Scheyd, G. J. (2005). The evolution of human physical attractiveness. Annual Review of Anthropology, 34, 523-548.

Geary, D. C., Vigil, J., \& Byrd-Craven, J. (2004). Evolution of human mate choice. Journal of Sex Research, 41, 27-42.

Halpern, C. T., Udry, J. R., Campbell, B., Suchindran, C., \& Mason, G. A. (1994). Testosterone and religiosity as predictors of sexual attitudes and activity among adolescent males: A biosocial model. Journal of Biosocial Science, 26, 217-234.

Halpern, C. T., Udry, J. R., \& Suchindran, C. (1997). Testosterone predicts initiation of coitus in adolescent females. Psychosomatic Medicine, 59, 161-171.

Hayes, N., \& Minardi, H. (2005). Psychology and ageing. In P. Woodrow (Ed.), Ageing: Issues for physical, psychological and social health (pp. 93-114). London and Philadelphia: Whurr Publishers Ltd.

Henry, L. (1961). Some data on natural fertility. Eugenics Quarterly, 8, 81-91.

Itier, R. J., \& Taylor, M. J. (2004). Face inversion and contrast-reversal effects across development: in contrast to the expertise theory. Developmental Science, 7, 246-260. 
Johnston, V. S., Hagel, R., Franklin, M., Fink, B., \& Grammer, K. (2001). Male facial attractivenessevidence for hormone-mediated adaptive design. Evolution and Human Behavior, 22, 251-267.

Jones, B. C., Little, A. C., Penton-Voak, I. S., Tiddeman, B. P., Burt, D. M., \& Perrett, D. I. (2001). Facial symmetry and judgements of apparent health. Support for a "good genes" explanation of the attractiveness-symmetry relationship. Evolution and Human Behavior, 22, 417-429.

Jones, B. C., Little, A. C., Burt, D. M., \& Perrett, D. I. (2004). When facial attractiveness is only skin deep. Perception, 33, 569-576.

Jones, B. C., Little, A. C., Boothroyd, L., DeBruine, L. M., Feinberg, D. R., Law Smith, M. J., et al. (2005). Commitment to relationships and preferences for femininity and apparent health in faces when progesterone level is high. Hormones and Behavior, 48, 283-290.

Jones, B. C., Perrett, D. I., Little, A. C., Boothroyd, L., Cornwell, R. E., Feinberg, D. R., et al. (2005). Menstrual cycle, pregnancy and oral contraceptive use alter attraction to apparent health in faces. Proceedings of the Royal Society B, 272, 347-354.

Jones, B. C., DeBruine, L. M., Little, A. C., \& Feinberg, D. R. (2007). The valence of experiences with faces influences generalized preferences. Journal of Cultural and Evolutionary Psychology, 5, 119129.

Jones, B. C., DeBruine, L. M., Perrett, D. I., Little, A. C., Feinberg, D. R., \& Law Smith, M. J. (2008). Effects of menstrual cycle phase on face preferences. Archives of Sexual Behavior, 37, 78-84.

Keating, C. F., \& Doyle, J. (2002). The faces of desirable mates and dates contain mixed social status cues. Journal of Experimental Social Psychology, 38, 414- 424.

Kościński, K. (2007). Facial attractiveness: General patterns of facial preferences. Anthropological Review, $70,45-79$.

Kościński, K. (2008). Facial attractiveness: Variation, adaptiveness and consequences of facial preferences. Anthropological Review, 71, 77-105.

Langlois, J. H., Roggman, L. A., Casey, R. J., Ritter, J. M., Rieser-Danner, L. A., \& Jenkins, V. Y. (1987). Infant preferences for attractive face: Rudiments of a stereotype? Developmental Psychology, 23, 363369.

Langlois, J. H., Ritter, J. M., Roggman, L. A., \& Vaughn, L. S. (1991). Facial diversity and infant preferences for attractive faces. Developmental Psychology, 27, 79-84.

Lebrun, C. E. I., Van Der Schouw, Y. T., De Jong, F. H., Pols, H. A. P., Grobbee, D. E., \& Lamberts, S. W. J. (2005). Endogenous oestrogens are related to cognition in healthy elderly women. Clinical Endocrinology, 63, 50-55.

Leifer, M. (1977). Psychological changes accompanying pregnancy and motherhood. Genetic Psychology Monographs, 95, 55-96.

Little, A. C., DeBruine, L. M., \& Jones, B. C. (2005). Sex-contingent face after-effects suggest distinct neural populations code male and female faces. Proceedings of the Royal Society B, 272, 2283-2287.

Little, A. C., Apicella, C. L., \& Marlowe, F. W. (2007). Preferences for symmetry in human faces in two cultures: Data from the UK and the Hadza, an isolated group of hunter-gatherers. Proceedings of the Royal Society B, 274, 3113-3117.

Little, A. C., Jones, B. C., Burt, D. M., \& Perrett, D. I. (2007). Preferences for symmetry in faces change across the menstrual cycle. Biological Psychology, 76, 209-216.

Little, A. C., Saxton, T. K., Roberts, S. C., Jones, B. C., DeBruine, L. M., Vukovic, J., et al. (2010). Women's preferences for masculinity in male faces are highest during reproductive age range and lower around puberty and post-menopause. Psychoneuroendocrinology, 35, 912-920.

Mathes, E. W., Brennan, S. M., Haugen, P. M., \& Rice, H. B. (1985). Ratings of physical attractiveness as a function of age. Journal of Social Psychology, 125, 157-168.

McGivern, R. F., Andersen, J., Byrd, D., Mutter, K. L., \& Reilly, J. (2002). Cognitive efficiency on a match to sample task decreases at the onset of puberty in children. Brain and Cognition, 50, 7389.

National Institutes of Health. (2010). National Library of Medicine - Medical Subject Headings. Available from http:/www.nlm.nih.gov/cgi/mesh/2010/MB_cgi?mode=\&index=11149. Accessed May 15, 2010.

O’Connor, K. A., Holman, D. J., Brindle, E., Barsom, S. H., \& Wood, J. W. (1998). Reproductive hormones and pregnancy-related sickness in a prospective study of Bangladeshi women. American Journal of Physical Anthropology, Suppl, 26, 172.

Pawłowski, B., \& Dunbar, R. I. M. (1999). Impact of market value on human mate choice decisions. Proceedings of the Royal Society of London B, 266, 281-285.

Penton-Voak, I. S., \& Perrett, D. I. (2000). Female preference for male faces changes cyclically: Further evidence. Evolution and Human Behavior, 21, 39-48. 
Penton-Voak, I. S., Little, A. C., Jones, B. C., Burt, D. M., Tiddeman, B. P., \& Perrett, D. I. (2003). Female condition influences preferences for sexual dimorphism in faces of male humans (Homo sapiens). Journal of Comparative Psychology, 117, 264-271.

Perrett, D. I., Lee, K. J., Penton-Voak, I., Rowland, D., Yoshikawa, S., Burt, D. M., et al. (1998). Effects of sexual dimorphism on facial attractiveness. Nature, 394, 884-887.

Regan, P. C. (1999). Hormonal correlates and causes of sexual desire: A review. The Canadian Journal of Human Sexuality, 8, 1-16.

Rhodes, G. (2006). The evolutionary psychology of facial beauty. Annual Review of Psychology, 57, $199-226$.

Rhodes, G., Sumich, A., \& Byatt, G. (1999). Are average facial configurations attractive only because of their symmetry? Psychological Science, 10, 52-58.

Rhodes, G., Jeffery, L., Watson, T. L., Clifford, C. W. G., \& Nakayama, K. (2003). Fitting the mind to the world: Face adaptation and attractiveness aftereffects. Psychological Science, 14, 558-566.

Roney, J. R., \& Simmons, Z. L. (2008). Women's estradiol predicts preference for facial cues of men's testosterone. Hormones and Behavior, 53, 14-19.

Roney, J. R., Hanson, K. N., Durante, K. M., \& Maestripieri, D. (2006). Reading men's faces: Women's mate attractiveness judgments track men's testosterone and interest in infants. Proceedings of the Royal Society B, 273, 2169-2175.

Rosen, M. L., \& López, H. H. (2009). Menstrual cycle shifts in attentional bias for courtship language. Evolution and Human Behavior, 30, 131-140.

Saxton, T. K., Cary, P. G., \& Roberts, S. C. (2006). Vocal and facial attractiveness judgments of children, adolescents and adults: The ontogeny of mate choice. Ethology, 112, 1179-1185.

Saxton, T. K., DeBruine, L. M., Jones, B. C., Little, A. C., \& Roberts, S. C. (2009). Face and voice attractiveness judgments change during adolescence. Evolution and Human Behavior, 30, $398-408$.

Saxton, T. K., Little, A. C., DeBruine, L. M., Jones, B. C., \& Roberts, S. C. (2009). Adolescents' preferences for sexual dimorphism are influenced by relative exposure to male and female faces. Personality and Individual Differences, 47, 864-868.

Scarbrough, P. S., \& Johnston, V. S. (2005). Individual differences in women's facial preferences as a function of digit ratio and mental rotation ability. Evolution and Human Behavior, 26, 509-526.

Sherman, P. W., \& Flaxman, S. M. (2002). Nausea and vomiting of pregnancy in an evolutionary perspective. American Journal of Obstetrics and Gynecology, 186, 190-197.

Sisk, C. L., \& Zehr, J. L. (2005). Pubertal hormones organize the adolescent brain and behavior. Frontiers in Neuroendocrinology, 26, 163-174.

Slater, A., Von der Schulenburg, C., Brown, E., Badenoch, M., Butterworth, G., Parsons, S., et al. (1998). Newborn infants prefer attractive faces. Infant Behavior \& Development, 21, 345-354.

Symons, D. (1979). The evolution of human sexuality. Oxford: University Press.

Symons, D. (1995). Beauty is in the adaptation of the beholder: The evolutionary psychology of human female sexual attractiveness. In P. R. Abramson \& S. D. Pinkerton (Eds.), Sexual nature/Sexual culture (pp. 80-118). Chicago: University of Chicago Press.

Tanner, J. M. (1962). Growth at adolescence. Oxford: Blackwell.

Theodoridou, A., Rowe, A. C., Penton-Voak, I. S., \& Rogers, P. J. (2009). Oxytocin and social perception: Oxytocin increases perceived facial trustworthiness and attractiveness. Hormones and Behavior, 56, 128-132.

Thornhill, R., \& Gangestad, S. W. (1993). Human facial beauty: Averageness, symmetry, and parasite resistance. Human Nature, 4, 237-269.

Traggiai, C., \& Stanhope, R. (2003). Disorders of pubertal development. Best Practice \& Research. Clinical Obstetrics \& Gynaecology, 17, 41-56.

Udry, J. R. (1965). Structural correlates of feminine beauty preferences in Britain and the United States: A comparison. Sociology and Social Research, 49, 330-342.

Vukovic, J., Jones, B. C., DeBruine, L. M., Little, A. C., Feinberg, D. R., \& Welling, L. L. M. (2009). Circummenopausal effects on women's judgements of facial attractiveness. Biology Letters, 5, 62-64.

Waynforth, D. (1999). Differences in time use for mating and nepotistic effort as a function of male attractiveness in rural Belize. Evolution and Human Behavior, 20, 19-28.

Welling, L. L. M., Jones, B. C., DeBruine, L. M., Conway, C. A., Law Smith, M. J., Little, A. C., et al. (2007). Raised salivary testosterone in women is associated with increased attraction to masculine faces. Hormones and Behavior, 52, 156-161.

Welling, L. L. M., Jones, B. C., DeBruine, L. M., Smith, F. G., Feinberg, D. R., Little, A. C., et al. (2008). Men report stronger attraction to femininity in women's faces when their testosterone levels are high. Hormones and Behavior, 54, 703-708. 
Wilcox, A. J., Dunson, D. B., Weinberg, C. R., Trussell, J., \& Day Baird, D. (2001). Likelihood of conception with a single act of intercourse: providing benchmark rates for assessment of post-coital contraceptives. Contraception, 63, 211-215.

Williams, C. L. (1998). Estrogen effects on cognition across the lifespan. Hormones and Behavior, 34, 8084.

Winter, J. S. D. (1978). Prepubertal and pubertal endocrinology. In F. Falkner \& J. M. Tanner (Eds.), Human growth (Vol. 2, pp. 183-213). New York: Plenum.

Wolf, N. (1991). The beauty myth: How images of beauty are used against women. New York: Morrow.

Żarów, R., \& Cichocka, B. A. (2008). A comparative analysis of estimation of age at menarche by various methods in women participating in the Krakow Longitudinal Growth Study, Poland. American Journal of Human Biology, 20, 146-148.

Krzysztof Kościński, Ph.D. is a researcher and lecturer in biological anthropology at the Adam Mickiewicz University in Poznań, Poland. His research interests focus on human mate choice with special reference to facial preferences. 